(RESEARCH ARTICLE)

\title{
Evaluation of activities of some plant leaf extract on typhoidal and non-typhoidal Salmonella isolate from selected hospitals in Bauchi, Nigeria
}

\author{
Naphtali Esther *, Tahir Fatima and Agbo Ediga B \\ Department of Microbiology, Abubakar Tafawa Balewa University, Bauchi, Nigeria. \\ Publication history: Received on 05 March 2020; revised on 05 May 2020; accepted on 07 May 2020
}

Article DOI: https://doi.org/10.30574/gscbps.2020.11.2.058

\begin{abstract}
This study evaluated the antibacterial activity of aqueous and methanol extracts of Cymbopogan citratus, Psidium guajava and Anacadium occidentale on clinical isolates of typhoidal and non typhoidal Salmonella. The typhoidal Salmonella isolates where $S$. typhi and S. paratyphi $A$, while non typhoidal was $S$. typhimurium. Well diffusion method was used. The plant extracts were tested individually and in combinations for synergistic activity. Both methanol and aqueous extracts had significant $(\mathrm{p}<0.05)$ in vitro activity. Anacadium occidentale was more active followed by Psidium guajava and the least active was Cymbopogan citratus with higher activity when plants extracts were combined for synergism. The Minimum Inhibitory Concentration (MIC) of extracts on the salmonella isolates ranged from $50 \mathrm{mg} / \mathrm{ml}$ to $200 \mathrm{mg} / \mathrm{ml}$ and the Minimum Bactericidal Concentration ranged from $25 \mathrm{mg} / \mathrm{ml}$ to $200 \mathrm{mg} / \mathrm{ml}$. From the findings, it proved that plants possess some potentials as antibiotics and can be further studied to isolate the compound that is most active and formulated as drug against the disease.
\end{abstract}

Keywords: Cymbopogan citratus; Psidium guajava; Anacadium occidentale; Synergism; (MIC); (MBC)

\section{Introduction}

Salmonelosis is a disease caused by salmonella species which are members of the family enterobacteriaceace. They are gram negative facultative anaerobic rods. Salmonella species are classified into serovars (serotypes) based on the lipopolysacharide (O) flagellar protein (H) and sometimes the capsular (VI) antigens. There are more than $2500 \mathrm{known}$ serovars, within a serovar, there may be strains that differ in virulence [12] Salmonella is generally divided into two categories; non typhoidal and typhoidal. The non typhoidal salmonella is the most common form and is carried by both humans and animals. Most serotypes of salmonella such as Salmonella jariana and Salmanolla entiritidis cause non typhoidal salmonellosis. Salmonella typhimurium is involved in the invasive non-typoidal. [12].

The serovars responsible for typhoid fever is restricted to human beings, which is transmitted through direct contact with the feacal matter of an infected person, that is to say it's transmitted through feaco-oral route. Typhoid fever is endemic in developing and under developed world where unsanitary conditions are more likely to prevail and which can affect as many as 21.5 million people, each year. Recorded cases of typhoid fever in the developed world are mostly related to recent travel to areas where, salmonella Typhoid is endemic.

Typhoid fever symptoms appear between 8-14 days after eating contaminated food and last anywhere from 3-60 days. They include fever, weakness, lethargy abdominal pain, coughing, nose bleeding and delirium and enlarged organs. Typhoid fever is a serious illness that can result in death [8].

\footnotetext{
* Corresponding author: Naphtali Esther
} 
Herbal medicine is still the main stay of about 75-80 \% of the world population, particularly, in developing countries for primary health care [11]. This is primarily because of the general belief that herbal drugs are without any side effects. Besides, they are cheap and locally available. Before scientists made impact into the research for drugs curing human infections, the traditional means of treating diseases were done by means of concoctions from plants either in single form or mixtures without knowing that the agents were used against some pathogenic micro-organism [19]. Limited knowledge about the practices of use of plant medication that is herbal medicine and lack of scientific studies of plants have led to the neglect of novel bioactive components that may bring about remarkable result in treatment of infectious diseases with little or no side effect [18].

In the last three decades, the search for natural bioactive compounds that can serve as antimicrobial agents had increased tremendously due to the increasing resistance possessed by microorganisms to synthetic antibiotic [15].

The scope of this study includes isolation of Salmonella, extraction of African lemon grass (Cymbopogan citratus) guava leaf (Psidium guajava) cashew leaf (Anacardium Occidentale) and the testing of the efficacy of these extract on the isolate.

\section{Material and methods}

\subsection{Ethical clearance}

The consent of the clinically suspected patients was sort, while the Ethics Committee of Abubakar Tafawa Balewa University teaching Hospital Bauchi gave approval for the study. Confidentiality of the subjects' identities was duly maintained.

\subsection{Study area}

The study area is Bauchi Local Government Area, where samples were collect from new General Hospital Bayara, Specialist Hospital and ATBU Teaching Hospital, Bauchi state is located on Lat. $10.6371^{\circ} \mathrm{N}$, long. $^{10.0807}{ }^{\circ} \mathrm{E}$ the vegetation is that of savanna and Sahel according to Koppen's climate classification system. Bauchi LGA is located on Lat. $10.301^{\circ} \mathrm{N}$ long. $9.8237^{\circ} \mathrm{E}$, it's area is 3,687 $\mathrm{km} 2$ and has population of 493,810 according to 2006 population census.

\section{Sample size/Sample population}

Sample size is 210 . Samples were collected from male, female and children. The sample size was determined using the Fisher formula for cross-sectional study [17].

\subsection{Sample collection}

\subsubsection{Clinical samples}

A total of 210 clinical samples were collected, blood and stool Samples were collected from patient with febrile or diarrheal illness attending new General Hospital Bayara, Specialist Hospital and ATBU Teaching Hospital, Bauchi on weekly basis from May to August 2016. Blood sample were collected using syringe and needle while stool samples were collected using sterile bottles, patient where served with sterile bottles to collect a small quantity of their stools.

\subsubsection{Plants collection and identification}

Plant samples collected or used are African lemon grass (Cymbopogan citratus), Cashew leaf (Anacardium Occidentale) and guava leaf (Psidium guajava). These were collected at Mbak area of Dass town a local government in Bauchi state where they are found to be growing naturally or planted and transported to ATBU herbarium for authentication with the following voucher numbers; Psidium guajava ATBUHB 2489, Anacardium Occidentale ATBUHB 2490 and Cymbopogan citratus ATBUHB 2491

\section{Isolation, characterization and identification of Typhoidal and non-Typhoidal Salmonella}

Stool sample were inoculated in a non-selective broth-selenite F enrichment broth and incubated at $37^{\circ} \mathrm{C}$ for $24 \mathrm{hrs}$, the pre cultured stool sample were sub cultured on deoxycholate citrate agar (DCA), salmonella shigella agar (SSA) agar and brilliant green agar (BGA) and incubated at $37^{\circ} \mathrm{C}$ for $18-24$ hrs where growth were detected based on their, colonial characteristic and morphological appearance on these media. 
Blood samples were inoculated into Terathionate broth. A minimum of blood to broth ratio of 1 in 10 mls, was maintained, and this was incubated at $37^{\circ} \mathrm{C}$ and checked for signs of bacterial growth daily for up to seven days. Bottles that show signs of growth were subculture on to Brilliant Green Agar (BGA) Salmonella Shegela Agar (SSA), and Mac conkey Agar.

Blood culture broth with no bacterial growth after seven days was sub-cultured before being reported as negative result. Typical colonies of Salmonella appear as pink colonies with or without black centers. Many cultures of Salmonella produce colonies with large, glossy black centers or may appear as almost completely black colonies. [22]

\subsection{Biochemical screening and serology}

Sugar fermentation tests

Nutrient broth cultures were prepared and used in Bijou bottles containing the basal medium and appropriately prepared. Carbohydrate (mannitol, maltose, dulcitol, sucrose and glucose) were inoculated with drop of the nutrient broth suspension of the test isolate and were loosely capped and incubated at $37^{\circ} \mathrm{C}$ overnight. They were observed for change in colour from amber to red and for gas production (in the medium filled inverted Durham tube) $[9,13]$

\subsection{Serotyping of identified Salmonella species}

Colonies considered to be of Salmonella spp. were further tested for somatic (O) and flagella (H) antigens with polyvalent antisera (OXOID), [9, 13].

\subsection{Antibacterial sensitivity of commonly used drug for Typhoid treatment}

The susceptibility testing was carried out by disc diffusion method using Mueller Hinton agar and it was tested in vitro for susceptibility to the following antibiotics (OXOID Ltd., UK) suggested by [23], Ciprofloxacin (CPX,10 $\mu \mathrm{g}$ ), Amoxicillin (AMC,30 $\mu \mathrm{g})$ and Chloramphenicol $(\mathrm{CH}, 30 \mu \mathrm{g})$.

\subsection{Plant sample preparation}

The leaves and grass were washed, drained and air dried at room temperature and grinded to powder using mortar and pestle. All the powdered samples were labelled and stored in a dark polythene bags at room temperature prior utilization [21].

\subsection{Extraction procedure of plants sample prepared}

100 grams of each powder plant sample stored were weighed and extracted with methanol and aqueous (Water) for 36 hours using soxhlet extractor [7].

\subsection{Preparation of inoculum}

McFarland standard; 0.5 McFarland standard was prepared by $0.5 \mathrm{ml}$ of $1 \%$ Barium chloride (BaCl2) to $99.5 \mathrm{mls}$ of 1 $\%$ Sulphuric acid (H2SO4). The turbidity of 0.5 McFarland standard was used for the estimation of the amount of salmonella. Colonies of Salmonella was suspended in sterilized $0.9 \%$ sodium chloride solution (normal saline) which was compared with $0.5 \mathrm{McF}$ arland solution the microbial suspension $(1 \mathrm{ml})$ in normal saline was added to $74 \mathrm{mls}$ of sterile medium kept at $45^{\circ} \mathrm{C}$ to give bacterial population density of $1.2 \times 107$ Cells $/ \mathrm{ml}$ [16].

\subsection{Preparation of stock suspension of extract}

Stock preparation of plant extract was prepared by dissolving 0.4 grams of extract in to 1 ml of dimethyl sulfoxide (DMSO) for methanol extract and $1 \mathrm{ml}$ sterilized distilled water was used for aqueous extract to make $400 \mathrm{mg} / \mathrm{ml}$ and stored at room temperature pending usage.

\subsection{Assays for antibacterial activity of plant extracts}

The antibacterial activity was carried out by well diffusion method [10]. Preparation of inoculums was obtained using McFarland standard to have inoculums density of $1.2 \times 107 \mathrm{Cfu} / \mathrm{mls}$, wells of $4 \mathrm{~mm}$ in diameter were bored on already inoculated Mueller Hilton agar plates using a sterile well borer and $60 \mu \mathrm{L}$ of extracts was dispensed in the wells and stand for $40 \mathrm{~min}$. as pre-diffusion time, these were incubated at $37{ }^{\circ} \mathrm{C}$ for $18-24 \mathrm{hr}$. Diameters of zones of inhibition was determined by subtracting the diameter of the wells and recorded to the nearest millimeter. 
Preliminary testing of this preparation was carried out using the stock concentration $400 \mathrm{mg} / \mathrm{ml}$ to test whether or not the plant is active. The antibacterial activity assay was done in duplicate at concentrations 400, 200, 10050 and 25 $\mathrm{mg} / \mathrm{ml}$ were the means were taken as the mean zones of inhibition (MZI). To investigate the synergistic activity of the extracts equal volume of $0.5 \mathrm{ml}$ from the stock preparation of both solvents, this combination was made in twos and the three and diluted to make concentration of 400,200,100, 50 and $25 \mathrm{mg} / \mathrm{ml}$.

\subsection{Determination of minimum inhibitory concentration (MIC) of extract against the bacteria}

This was determined by serial dilution method, where different concentration was obtained. $0.4 \mathrm{~g}$ of the Stock solution prepared from plant extract was dissolved in $1 \mathrm{ml}$ of DMSO, making a solution of $400 \mathrm{mg} / \mathrm{ml}$ from where serial dilution of different concentrations was made $200 \mathrm{mg} / \mathrm{ml}, 100 \mathrm{mg} / \mathrm{ml}, 50 \mathrm{mg} / \mathrm{ml}$, and $25 \mathrm{mg} / \mathrm{ml}$. Nutrient broth was used to produce overnight growth; $0.1 \mathrm{ml} \mathrm{McFarland} \mathrm{standard} \mathrm{inoculums} \mathrm{was} \mathrm{inoculated} \mathrm{in} \mathrm{the} \mathrm{tubes} \mathrm{and} \mathrm{incubated} \mathrm{at} 37{ }^{\circ} \mathrm{C}$ for $24 \mathrm{hr}$. The tubes least turbidity (bacterial growth) was the MIC. [14]

\subsubsection{Determination of minimum bactericidal concentration (MBC)}

The above tube that showed no bacterial growth was further subculture on to Mueller Hilton agar incubated at $37^{\circ} \mathrm{C}$ for 18-24 hr. The least plate that showed no bacterial growth was the MBC. [14]

\section{Results and discussion}

\subsection{Determination of activity of extract on bacterial isolates}

The crude methanol and aqueous extract of Anacadium occidentale, Psidium guajava and Cymbopogan citratus was tested on S. typhi, these have MZI range as 0-19 mm Table 1, when tested on S. paratyphi A. it gave MZI range as 0-19.5 $\mathrm{mm}$ Table 2 and when it was tested on S. typhimurium the MZI ranged from 0-17 mm Table 3.

Table 1 Activity of individual plant extract on Salmonella typhi (Typhoidal)

\begin{tabular}{|c|c|c|c|c|c|c|}
\hline \multicolumn{7}{|c|}{ Mean Zone of Inhibition in (mm) } \\
\hline \multirow[t]{2}{*}{$\begin{array}{l}\text { Concentration of plant } \\
\text { extract in } \mathrm{mg} / \mathrm{ml}\end{array}$} & \multicolumn{2}{|c|}{ Cymbopogan citratus } & \multicolumn{2}{|c|}{ Psidium guajava } & \multicolumn{2}{|c|}{$\begin{array}{l}\text { Anacadium } \\
\text { occidentale }\end{array}$} \\
\hline & $\mathrm{ME}$ & $\mathrm{AE}$ & $\mathrm{ME}$ & $\mathrm{AE}$ & $\mathrm{ME}$ & $\mathrm{AE}$ \\
\hline 400 & 9 & 11 & 17 & 16 & 19 & 13 \\
\hline 200 & 5 & 10 & 17 & 15 & 15 & 10.5 \\
\hline 100 & 2 & 7 & 14 & 13 & 11 & 10.5 \\
\hline 50 & 2 & 4 & 11 & 9 & 8.5 & 6.5 \\
\hline 25 & 0 & 0 & 4 & 4 & 4.5 & 5 \\
\hline
\end{tabular}

Key: $\mathrm{ME}=$ Methanol Extract, $\mathrm{AE}=$ Aqueous Extract

Table 2 Activity of individual plant extracts on Salmonella Paratyphi A. (Typhoidal)

\begin{tabular}{|c|c|c|c|c|c|c|}
\hline \multicolumn{7}{|c|}{ Mean Zone of Inhibition in (mm) } \\
\hline \multirow[t]{2}{*}{$\begin{array}{l}\text { Concentration of plant } \\
\text { extract in } \mathrm{mg} / \mathrm{ml}\end{array}$} & \multicolumn{2}{|c|}{ Cymbopogan citratus } & \multicolumn{2}{|c|}{ Psidium guajava } & \multicolumn{2}{|c|}{$\begin{array}{l}\text { Anacadium } \\
\text { occidentale }\end{array}$} \\
\hline & ME & $\mathrm{AE}$ & $\mathrm{ME}$ & $\mathrm{AE}$ & ME & $\mathrm{AE}$ \\
\hline 400 & 5 & 6.5 & 17 & 18.5 & 19.5 & 17 \\
\hline 200 & 5.5 & 2 & 14.5 & 13 & 16 & 16 \\
\hline 100 & 3 & 0 & 10 & 12 & 16.5 & 11 \\
\hline 50 & 1 & 0 & 8 & 5 & 10 & 9 \\
\hline 25 & 0 & 0 & 5 & 6 & 6 & 6 \\
\hline
\end{tabular}

Key: $\mathrm{ME}=$ Methanol Extract, $\mathrm{AE}=$ Aqueous Extract 
Table 3 Activity of individual plant extract on Salmonella typhimurium (Non-Typhoidal)

\begin{tabular}{lllllll}
\hline Mean Zone of Inhibition in $\mathbf{( m m})$ & & & & \\
\hline $\begin{array}{l}\text { Concentration of plant } \\
\text { extract in } \mathbf{~ m g / m l ~}\end{array}$ & \multicolumn{2}{l}{ Cymbopogan citratus } & \multicolumn{2}{l}{ Psidium guajava } & \multicolumn{2}{l}{$\begin{array}{l}\text { Anacadium } \\
\text { occidentale }\end{array}$} \\
& $\mathrm{ME}$ & $\mathrm{AE}$ & $\mathrm{ME}$ & $\mathrm{AE}$ & $\mathrm{ME}$ & $\mathrm{AE}$ \\
\hline 400 & 14 & 11 & 11 & 14 & 17 & 17 \\
200 & 9 & 2 & 10 & 11 & 15 & 11 \\
100 & 3 & 1 & 5 & 6 & 13.5 & 6.5 \\
50 & 1 & 0 & 3 & 3.5 & 13.5 & 5 \\
25 & 0 & 0 & 1 & 3 & 10 & 3 \\
\hline
\end{tabular}

\subsection{Screening for synergistic activity of extracts on bacterial isolates}

The result of the combination of extract in different combinations according to Solvents used varying ranges of MZI was observed. The activity of combination of two extracts on S. typhi have MZI range from 2-23 mm Table 4, on S. Paratyphi A have MZI range from 1-19 $\mathrm{mm}$ Table 5, when it was tested on $S$. typhimurium it gave MZI range from 1-15 mm Table 6 . Table 7 is a result of when the three extracts where combined together depending on solvent and tested on the isolates, MZI result ranged from 2-17.5 mm.

Table 4 Activity of combined plant extracts for synergy on Salmonella typhi (Typhoidal)

\begin{tabular}{|c|c|c|c|c|c|c|}
\hline \multirow{3}{*}{$\begin{array}{l}\text { Concentration of plant extract } \\
\text { in } \mathrm{mg} / \mathrm{ml}\end{array}$} & \multicolumn{6}{|c|}{ Mean Zone of Inhibition in (mm) } \\
\hline & \multicolumn{2}{|c|}{$(P g$ and $C c)$} & \multicolumn{2}{|c|}{ (Pg and Ao) } & \multicolumn{2}{|c|}{ (Ao and $C c)$} \\
\hline & ME & $\mathrm{AE}$ & ME & $\mathrm{AE}$ & ME & $\mathrm{AE}$ \\
\hline 400 & 19.5 & 17 & 23 & 16 & 17 & 19 \\
\hline 200 & 17 & 15 & 20 & 11 & 11 & 11.5 \\
\hline 100 & 15 & 6.5 & 13 & 9 & 10 & 4 \\
\hline 50 & 3.5 & 3 & 12 & 8 & 10 & 2 \\
\hline 25 & 3 & 2 & 9 & 4 & 7 & 1 \\
\hline Positive control streptomycin $1 \mathrm{~g}$ & 22 & 20 & 20 & 20 & 22 & 22 \\
\hline Negative control DMSO & 0 & 0 & 0 & 0 & 0 & 0 \\
\hline
\end{tabular}

Table 5 Activity of combined plant extracts for synergy on salmonella Paratyphi A. (Typhoidal)

\begin{tabular}{|c|c|c|c|c|c|c|}
\hline \multirow{3}{*}{$\begin{array}{l}\text { Concentration of plant extract in } \\
\mathrm{mg} / \mathrm{ml}\end{array}$} & \multicolumn{6}{|c|}{ Mean Zone of Inhibition in (mm) } \\
\hline & \multicolumn{2}{|c|}{ (Pg and $C c)$} & \multicolumn{2}{|c|}{ (Pg and Ao) } & \multicolumn{2}{|c|}{$($ Ao and $C c)$} \\
\hline & ME & $\mathrm{AE}$ & ME & $\mathrm{AE}$ & $\mathrm{ME}$ & $\mathrm{AE}$ \\
\hline 400 & 18 & 15 & 19 & 14 & 16.5 & 14 \\
\hline 200 & 12 & 12 & 17 & 10 & 14 & 11.5 \\
\hline 100 & 10 & 9 & 15 & 9 & 11.5 & 10 \\
\hline 50 & 8.5 & 5 & 8 & 6 & 10 & 8 \\
\hline 25 & 8 & 1 & 8 & 3 & 9.5 & 5 \\
\hline Positive control streptomycin lg & 24 & 22 & 22 & 20 & 22 & 20 \\
\hline Negative control DMSO & 0 & 0 & 0 & 0 & 0 & 0 \\
\hline
\end{tabular}


Table 6 Activity of combined plant extracts for synergy on Salmonella typhimurium (Non-Typhoidal)

\begin{tabular}{|c|c|c|c|c|c|c|}
\hline \multicolumn{7}{|c|}{ Mean Zone of Inhibition in (mm) } \\
\hline \multirow{2}{*}{$\begin{array}{l}\text { Concentration of } \\
\text { plant extract in } \\
\mathrm{mg} / \mathrm{ml}\end{array}$} & \multicolumn{2}{|c|}{ (Pg and $C c)$} & \multicolumn{2}{|c|}{ (Pg and Ao) } & \multicolumn{2}{|c|}{ (Ao and $C c$ ) } \\
\hline & ME & $\mathrm{AE}$ & $\mathrm{ME}$ & $\mathrm{AE}$ & ME & $\mathrm{AE}$ \\
\hline 400 & 20 & 17 & 18 & 16 & 17 & 15 \\
\hline 200 & 13.5 & 9 & 18 & 15 & 17 & 12 \\
\hline 100 & 12 & 7 & 14 & 12 & 15 & 6 \\
\hline 50 & 12 & 4 & 10 & 5 & 12 & 6 \\
\hline 25 & 11 & 1 & 8 & 3 & 9 & 4 \\
\hline $\begin{array}{l}\text { Positive control } \\
\text { streptomycin lg }\end{array}$ & 22 & 20 & 20 & 20 & 22 & 22 \\
\hline $\begin{array}{l}\text { Negative control } \\
\text { DMSO }\end{array}$ & 0 & 0 & 0 & 0 & 0 & 0 \\
\hline
\end{tabular}

Table 7 Activity of combination of the three plants extracts for synergy on the three Salmonella Soretypes

\begin{tabular}{|c|c|c|c|c|c|c|}
\hline \multicolumn{7}{|c|}{ Mean Zone of Inhibition in ( $\mathrm{mm}$ ) } \\
\hline \multirow{2}{*}{$\begin{array}{l}\text { Concentration of } \\
\text { plant extract in } \\
\mathrm{mg} / \mathrm{ml}\end{array}$} & \multicolumn{2}{|c|}{ S. Typhi } & \multicolumn{2}{|c|}{ S. Paratyphi A. } & \multicolumn{2}{|c|}{ S. Typhimurium } \\
\hline & ME & $\mathrm{AE}$ & ME & $\mathrm{AE}$ & ME & $\mathrm{AE}$ \\
\hline 400 & 17.5 & 15 & 17 & 15 & 18 & 16 \\
\hline 200 & 14 & 14 & 13 & 13 & 15 & 14 \\
\hline 100 & 13 & 12 & 10 & 11 & 14 & 12.5 \\
\hline 50 & 10 & 5 & 9 & 7 & 12 & 11 \\
\hline 25 & 5 & 4 & 6 & 2 & 9 & 6.5 \\
\hline $\begin{array}{l}\text { Positive control } \\
\text { streptomycin lg }\end{array}$ & 20 & 22 & 22 & 20 & 20 & 20 \\
\hline $\begin{array}{l}\text { Negative control } \\
\text { DMSO }\end{array}$ & 0 & 0 & 0 & 0 & 0 & 0 \\
\hline
\end{tabular}

Key: $\mathrm{Pg}=$ Psidium guajava, $\mathrm{Ao}=$ Anacadium occidentale, $\mathrm{Cc}=$ Cymbopogan citratus

$\mathrm{ME}=$ Methanol Extract, $\mathrm{AE}=$ Aqueous Extract

\subsection{Comparative antibacterial activity of different plant samples used}

The inhibitory activity of different plant extract at concentration $400 \mathrm{ml} / \mathrm{ml}$ showed different inhibitory patterns, Figures 1, 2 and 3. Anacadium occidantale $(A o)$ of methanol extract have higher activity ranging from 17-19.5 mm MZI followed by Psidium guajava $(P g)$ 14-17 mm MZI then Cymbopogan citratus (Cc) having range from 5-14 mm MZI, aqueous extract had these range, $(A o)$ 13-17 mm MZI, $(P g)$ 14-18.5 mm MZI and $(C c)$ 6.5-11 mm MZI figure 1. On figure 2 Combination of two extracts according to solvents have MZI as- methanol extracts range of $18-20 \mathrm{~mm} \mathrm{MZI}$, on $(\mathrm{Pg}$ and $C c$ ), combination $(P g$ and $A o$ ) have MZI range from $18-23 \mathrm{~mm}$ and $(A o$ and $C c$ ) combination have MZI range from $16.5-$ $17 \mathrm{~mm}$. aqueous extract have MZI ranges as these; $(P g$ and $C c)$ have $15-1 \mathrm{~mm}$ MZI, $(P g$ and $A o$ ) have 14-16 mm and $(A o$ and $C c$ ) have 14-19 $\mathrm{mm}$. 
Figure 3 showed activities when extract was combined into three according to solvent, methanol extract had activity on S. Typhi with MZI $17.5 \mathrm{~mm}$, S. Paratyphi A. $17 \mathrm{~mm}$ and S. Typhimunium $18 \mathrm{~mm}$, aqueous extract had MZI on S. typhi 15 $\mathrm{mm}$, S. paratyphi A. $15 \mathrm{~mm}$ and S. typhimurium $16 \mathrm{~mm}$.

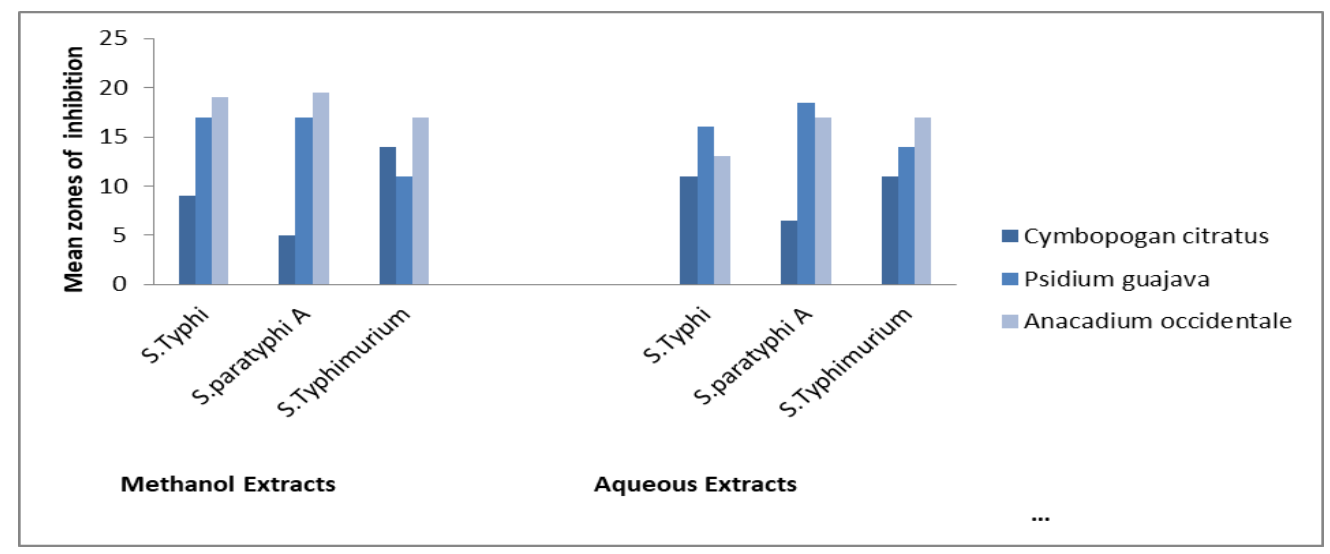

Figure 1 Comparative antibacterial activity of the individual plant extracts at ( $400 \mathrm{mg} / \mathrm{ml})$ on clinical Salmonella isolates.

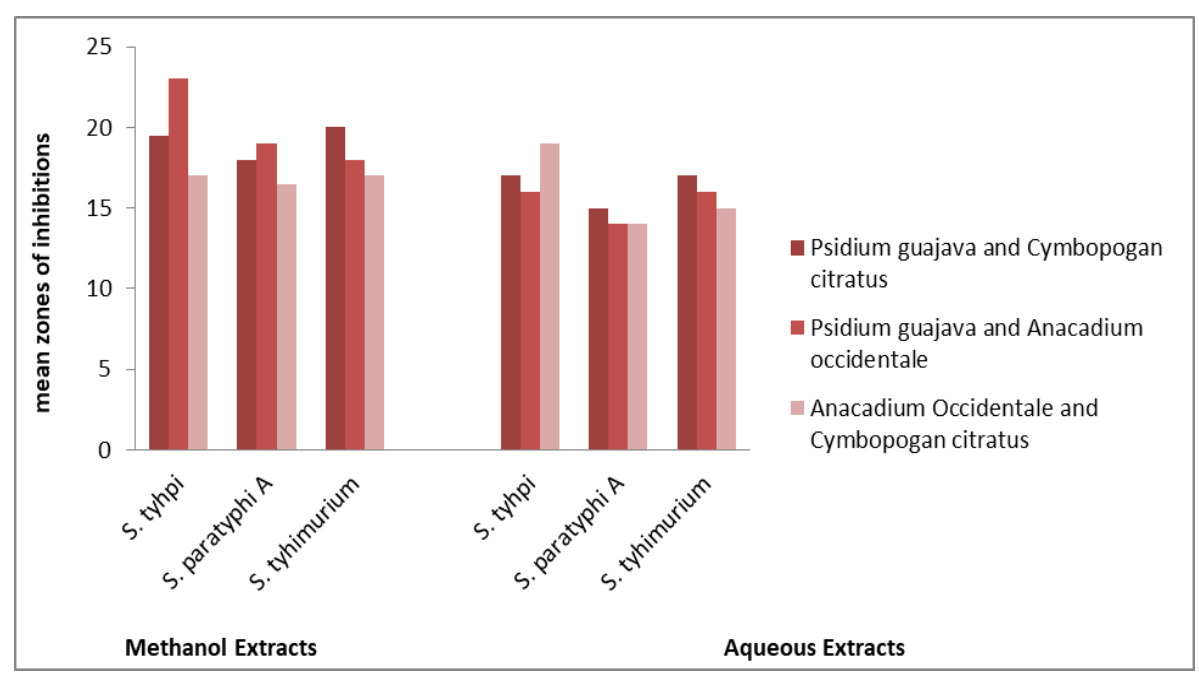

Figure 2 Comparative antibacterial activity of combinations of two plant extracts at ( $400 \mathrm{mg} / \mathrm{ml}$ ) on clinical Salmonella isolates.

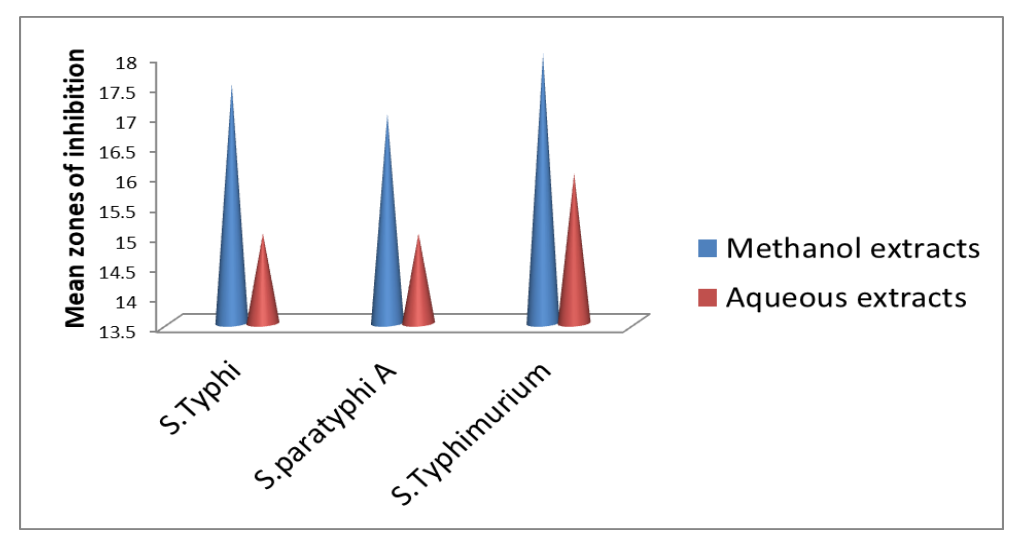

Figure 3 Comparative antibacterial activity of combination of the three plant extracts at ( $400 \mathrm{mg} / \mathrm{ml}$ ) on clinical Salmonella isolates 


\subsection{Antibacterial activity of extract}

The inhibitory activity of all the crude plant methanol and aqueous extract against the typhoidal and non-typhoidal Salmonella isolates with A. occidental, and P. guajava being the most active Tables 1, 2 and 3 is in conformity with other reports by [6]. This justifies the use of these plants for Therapeutic purposes. The result clearly revealed pronounced activity with methanol extract on the organism than aqueous extracts,

This could be as a result of the antibacterial compounds present in the plant which may be more readily extracted with methanol than aqueous solvents. Data reports have shown that some antimicrobial agents are not extractible with aqueous solvents $[5,20]$. The serotype that showed more susceptibility to the extracts is the non typhoidal, $S$. typhimurium followed by $S$. Paratyphi A. and $S$. typhi has the least susceptibility this could be due to its resistance and virulence as studied by so many researchers. [1,2].

The high antimicrobial potential of many of these plants extracts against test organism is of obvious public health importance. Typhoid fever no doubt is frequently connected to resistance with a number of commercial antibiotics which result into complication as arthritis intestinal perforation and of course death.

The body on the other hand has been observed to accommodate plant extracts at relatively high dose, without visible side effects [3]. The stability of the natural drugs to antimicrobial resistance by the organisms is also an advantage.

\subsection{Synergetic activity of extracts}

The methanol and aqueous extracts where combined to observe for synergetic effect and the study revealed that the combination of the plant extract has higher antibacterial activity effects (Synergism) having a higher inhibitory effect than when used singly as shown on tables $4,5,6$ and 7. This clearly indicates that single plant extract could cause inhibitory effect ranging from $0-19 \mathrm{~mm}$. However, when extract was combined the inhibitory surpassed that of single plant, $0-22 \mathrm{~mm}$ in combination of two tables 4, 5 and 6 and $2-19 \mathrm{~mm}$, with combination of the three plants as on table 7. The synergetic effect may be due to formation of certain complexes which becomes more effective in the inhibition on the organism, similar conclusions were drawn by $[10,24]$.

\subsection{Minimum inhibitory concentration (MIC) of extracts}

A result of MIC for various species of salmonella subjected to the different plant extracts is presented on Table 8. The MIC of $(A o)$ on $S$. typhi with methanol extract was $50 \mathrm{mg} / \mathrm{ml}$ and aqueous extract $100 \mathrm{mg} / \mathrm{ml}$, on $S$. paratypi A., both extracts was $50 \mathrm{mg} / \mathrm{ml}$, on $S$. typhimurium was $100 \mathrm{mg} / \mathrm{ml}$ with methanol extract and aqueous extract was $50 \mathrm{mg} / \mathrm{ml}$.

The MIC of $(P g)$ with methanol extract on $S$. tyhi was $50 \mathrm{mg} / \mathrm{ml}$ and aqueous extract $100 \mathrm{mg} / \mathrm{ml}$, on $S$. paratyphi A., was $50 \mathrm{mg} / \mathrm{ml}$ for both solvents extract, on $S$. typhimurium methanol extract was $100 \mathrm{mg} / \mathrm{ml}$ and aqueous $200 \mathrm{mg} / \mathrm{ml}$.

The MIC of $(C c)$ was $200 \mathrm{mg} / \mathrm{ml}$ for both solvent extract for the three salmonella isolates.

Table 8 Minimum inhibitory concentration of plants extracts on Salmonella Isolates

\begin{tabular}{|c|c|c|c|c|c|c|}
\hline \multicolumn{7}{|c|}{ Minimum inhibitory concentration (MIC) in $(\mathrm{mg} / \mathrm{ml})$} \\
\hline \multirow[t]{2}{*}{ Organism } & \multicolumn{2}{|c|}{ A. occidentale } & \multicolumn{2}{|c|}{ P.guajava } & \multicolumn{2}{|c|}{ C. citratus } \\
\hline & ME & $\mathrm{AE}$ & ME & $\mathrm{AE}$ & ME & $\mathrm{AE}$ \\
\hline \multicolumn{7}{|l|}{ 1.typhoidal } \\
\hline S. typhi & 50 & 100 & 50 & 100 & 200 & 200 \\
\hline S. paratyphi $A$ & 50 & 50 & 50 & 50 & 200 & 200 \\
\hline \multicolumn{7}{|l|}{ 2.non-typhoidal } \\
\hline S. typhimuriumm & 100 & 50 & 100 & 200 & 200 & 200 \\
\hline
\end{tabular}

\subsection{Minimum bactericidal concentration (MBC)}

Result of MBC is as shown on Table 9. The MBC of $(A o)$ of both solvent extracts on the isolates was $25 \mathrm{mg} / \mathrm{ml}$ except for $S$. typhimurium on aqueous extract which is $50 \mathrm{mg} / \mathrm{ml}$. The MBC of $(P g)$ extract of both solvents on $S$. typi and $S$. 
typhimurium was $50 \mathrm{mg} / \mathrm{ml}$ and on $S$. paratyphi A. was $25 \mathrm{mg} / \mathrm{ml}$. The MBC of $(C c)$ extract of both solvents on $S$. typhi was $50 \mathrm{mg} / \mathrm{ml}$, on S. paratyphi A. was $100 \mathrm{mg} / \mathrm{ml}$ with methanol extract with and $200 \mathrm{mg} / \mathrm{ml}$ with aqueous extract while on $S$. typhimurium had MBC $100 \mathrm{mg} / \mathrm{ml}$ with methanol extract and $200 \mathrm{mg} / \mathrm{ml}$ with aqueous extract.

Table 9 Minimum bactericidal concentration of plants extract on Salmonella isolates

\begin{tabular}{|c|c|c|c|c|c|c|}
\hline \multicolumn{7}{|c|}{ Minimum bacterial concentration (MBC) in (mg/ml) } \\
\hline \multirow[t]{2}{*}{ Organism } & \multicolumn{2}{|c|}{ A. occidentale } & \multicolumn{2}{|c|}{ P. guajava } & \multicolumn{2}{|c|}{ C. citratus } \\
\hline & $\mathrm{ME}$ & $\mathrm{AE}$ & $\mathrm{ME}$ & $\mathrm{AE}$ & $\mathrm{ME}$ & $\mathrm{AE}$ \\
\hline \multicolumn{7}{|l|}{ 1.typhoidal } \\
\hline S. typhi & 25 & 25 & 50 & 50 & 50 & 50 \\
\hline S. paratyphi $A$ & 25 & 25 & 25 & 25 & 100 & 200 \\
\hline \multicolumn{7}{|l|}{ 2.non-typhoidal } \\
\hline S. typhimuriumm & 50 & 50 & 50 & 50 & 100 & 200 \\
\hline
\end{tabular}

\section{Conclusion}

Result obtained from this study indicates that the leaves of Psidium guajava, Anacadium occidentale and Cymbopogan citratus (grass) inhibited the medically important Bacteria-Salmonella species. This proves that the plant possesses some potential as alternative sources of antimicrobial substances.

\section{Recommendation}

Since herbal products are better in combinations as revealed by this studies, further work is required to carry out a further study into possible combinations of these extracts that would give an enhanced and exploitable activity by synergistic or additive reasons in a single therapeutic formulation. This will offer an advantage of using lower but effective therapeutic dosage of natural product as compared to the dose of synthetic substance that would be required to achieve similar therapeutic effect.

\section{Compliance with ethical standards}

In compliance with the ethical standard the consent of the clinically suspected patients was sort, while the Ethics Committee of Abubakar Tafawa Balewa University teaching Hospital Bauchi gave approval for the research. Confidentiality of the subjects' identities was duly maintained. Attached is a copy of the ethical approval and consent form.

\section{Acknowledgments}

Our profound and immense appreciation goes to God Almighty who brought us thus far, to Him be all the glory, honour and adoration. Our appreciation goes to Head of Biological science department ATBU, Dr. A.B Samaila and the entire staff of the department, who gave us their moral and academic support and also made many useful suggestions. We also want to acknowledge Musa Muktari, Saidu Abubakar and Abdullahi Yahaya Mohammed of Biochemistry and Microbiology Department Gombe State University, for the permission to use their laboratory and also helped us in plant extraction and phytochemical screening. We gratefully acknowledge the constructive inputs, support and encouragement from colleagues, family and friends throughout the period of this research.

\section{Disclosure of conflict of interest}

The authors whose names are mentioned above declare that they have no conflict of interest as far as this publication is concerned, and should there be any conflict that may arise, it can be resolved amicably. The research is solely sponsored by the corresponding author. 


\section{References}

[1] Abdullahi B, Abdulfatai K, Wartu JR, Mohammed HID and Abdulsalam AO. (2014). Antibiotics Susceptibility patterns and characterization of clinical Salmonella Serotypesin Katsina State African Journal of Microbiology, Research, 8(a), 915 - 921.

[2] Ajayi OE, SI Awala, FN Okogbbue, AG Ogunleye and BF Olaleye. (2016). Antibacterial efficacy of Ageratum conyzoides on salmonella species isolated from suspected Typhoid fever patient in Akure metropolis, Nigeria. Journal of advances in medical and pharmaceutical sciences. 6(2).

[3] Ameenah G and Anwari. It's validating Ethnomedicine with a view to developing new Drugs (Unpublished). 2nd Edition. Spectrum Books Limited, Ibadan, Nigeria, 1-153.

[4] Amrit pal singh. (2005). promising phytochemical from indian medicinal plants Ethnobotoanicals leaflets. Vol. 1, 18.

[5] Awa Elizabeth Ihekerenma. (2011). photochemical screening and antimicrobial assay of some Nigerian medicinal plants Against Opportunistic pathogens in HIV/Aids patients. Unpublished M. microbiology thesis, 12-1.

[6] Ayman A and Mazen S. (2014). Inutro Antibacterial Activity of Several plant extracts and oils against some Grame Negative Bacteria Iranian Journal of Medicine sciences, 39(i), 36-43.

[7] Benson H J. (2002) Microbiology Application: Laboratory Manual in General Microbiology 8th Edition Mc Graw Hill New York fig 21-1 87. Bacterial population counts ICBN N 0-7 - 281889=9.

[8] CDC-Centre for Disease Control and Prevention. (2008). Multistate outbreaks of Salmonella typhimurium infections linked to peanut butter 2008-2009 (final update).

[9] Cheesbrough M. (2006). Salmonella species. In District Laboratory Practice in Tropical Countries. Low-priced ed. Cambridge, 182-186.

[10] Chukwura EI and Iheukwumere IA. (2012). Determination of Synergistic effect and activity index of Solenostemon monstachyus and ocimum gratissimum on selected bacteria. Nigeria, Journal of microbiology, 26, $2492-2497$.

[11] Guyton and Hall. (2000). Text book of Medical Physiology 12th edition.

[12] Jawetz Melnick and Adelberg Medical microbiology. (2013). 26th edition, 238-239.

[13] Perilla M, Ajello G, Bopp C, Elliott J and Facklam R. (2003). Manual for the laboratory identification and antimicrobial susceptibility testing of bacterial pathogens of public health importance in the developing world. Hemophilus influenza Neisseria meningitidis Streptococcus pneumoniae Neisseria gonorrhoeae Salmonella serotype Typhi Shigella and Vibriocholerae.

[14] Ogundare AO. (2011). Antibacterial properties of the leaf extracts of Vernonia amygdalina, Ocimum gratissium, Corchorous olitorius and Manihot palmate Nigerian of Journal of Microbiology, 25, 2269-2279.

[15] Oyetayo VO. (2009). Free radical scavenging and antimicrobial properties of extracts of wild mushrooms Brazilian journal of microbiology, 40, 380-386.

[16] Runyoro KB, Deborah M, Olipa D, Cosam CD and Zakaria HM. (2016). screeming of Tanzian Medicinal plants for anticandidial activity Bank Complementary and Alternative Medicine 6.

[17] Sambo AA. (2005). Research Method in Education sirling Harden Publishers (Nig) Ltd, 46-77.

[18] Slayer AA and whiff DO. (1994). Bacteria pathogens 1st edition AMS press Washington DC, 120 -204.

[19] Sofowara A. (1999). Medical plants and traditional medicine in Africa 3rd edition spectrum books limited Ibadan, $172-108$.

[20] Thompson GR, Petal P, West book SD, Berg D, Erlanse J, Redding SW and Peterson TF. (2009). Pharyngeal candiasis in the era of antiretroviral therapy. Oral surgery, oral medicine, oral apthology, oral radiology and endontology, 109 (4), 488 - 495

[21] Titilayo OY, Ogundare AO and Olaitan JO. (2011). Mechanism of action of the leaf and back extract of Veronica tenoreana Nigerian of Journal of Microbiology, 25, 2261-2268.

[22] United States Department of Agriculture food safety and inspection service (USDFSIS) Salmonella question and answers USDA FSIS (1998) 
[23] WHO. (2010). Laboratory protocol susceptibility testing of enterobacteriacae using disk diffusion WHO Global food borne infection Network

[24] Zafar A, Shaukati SK and Mohnaaz K. (2010). Synergistic effect of Salvadora persica extracts tetracycline and penicillin against staphyloccus aureus. A. J Basic and App. Sci., 2, 25-29.

\section{How to cite this article}

Naphtali E, Tahir F and Agbo EB. (2020). Evaluation of activities of some plant leaf extract on typhoidal and nontyphoidal Salmonella isolate from selected hospitals in Bauchi, Nigeria. GSC Biological and Pharmaceutical Sciences, $11(2), 20-30$. 